Finding, however, that other neighbours had noticed the same thing, and that at Golden Grove, near Roscrea, the workmen had observed that not only the water in the barrels was black, and was even next morning "like ink," but also that there was a decided blackness and scum in the pools on the carriage drive, at some distance from any chimney, I was convinced that the blackness had come from the thunder-cloud.

At so great a distance (about 200 miles) from any large smokeproducing town this was somewhat remarkable.

I was able to procure from one place, from near Eyrecourt, Co. Galway, through the kindness of the Rev. C. Lawrence, of Lisreaghan, Eyrecourt, a sample of the water. It is stated to have been of a dark blue colour, but when it reached my hands it had become pale reddish brown, with a considerable amount of solid matter in suspension.

Dr. W. J. Russell, F.R S., has been good enough to examine the sample, which appears to behave in all respects much as London rain water, except in being free from acid reaction (this may be due to previous impurity in the collecting vessel). The amount of sulphates is represented by 0.074 gramme of $\mathrm{H}_{2} \mathrm{SO}_{4}$, and of chlorides by 0.066 gramme of $\mathrm{HCl}$, in a litre. The solid matter is devoid of structure or of crystalline form, and appears to be soot. The specimen is, however, the less satisfactory from having been taken from near a house where coal has been burnt.

I understand that the rain was black near Shinrone, King's County, and that a few blackish drops were noticed at Dundrum, near Cashel. From Ballymore Castle, near Eyrecourt, where the sample was obtained, to Golden Grove, the distance is about 23 statute miles, and Shinrone is between them. From Eyrecourt to Dundrum is about 48 miles. Mr. Lawrence tells me that the blackness of the rain was noticed by several of his neighbours, and that a laundress kept the water three weeks in the barrels, and had then to reject it, as it was still too much dis. coloured.

Possibly it may be worth noting that two days before (April Io) there was an intense blackness like that of a moonless night in London, between 12.30 and 1.30 p.m., but I have at present no evidence to connect it with the phenomenon above described.

Athenæum Club, S. W., June is. Rosse.

\section{On the Theory of Hail.}

IN last week's NATURE (p. I5 I) Prof. Robinson gives an account of a bailstone that fell at Liverpool on the 2nd instant, consist. ing of an opaque nucleus, surrounded by almost clear ice, and this by opaque ice.

Hailstones formed of concentric layers, like the coats of an onion, are by no means uncommon. The number of layers has been known to amount to as many as thirteen (American Fournal of Science, 1., 403); but the statement that such a structure is formed, as Prof. Robinson supposes, "during electric oscillation from cloud to cloud," belongs to a theory that has often been disproved. Nor would it probably have excited much attention, but that it originated with no less a man than Volta, who, seeing how pith balls and other light objects oscillated between two metal plates in opposite electrical states, imagined that the hailstone acquired its successive coatings by oscillating between two clouds in opposite states, until its weight became too great for the electric force to sustain it against the gravitating force.

The two most distinguished writers who have examined this theory, and have shown its futility are Kämtz (Iehrbuch der Meteorolo zie, ii. 525) and Becquerel ("Traité de l'Electricité," iv. $(5 \mathrm{I})$.

The theory of hail which scientific meteorologists now accept, originated with Prof. Olmsted, of Yale College (I have not the reference at hand to the American Fournal of Science, but see Edin. New Phil. Fourn., ix. 244). This theory has received its finishing touches in the papers of the United States Coasts Survey ("Meteorological Researches for the use of the Coast Pilot," Part ii., p. 85, Washington, I880). The writer is Mr. William Ferrel.

Limiting our notice to such compound hailstones as the one described by Prof. Robinson, which from their size and velocity are the most destructive, and are produced during a tornado or a violent thunderstorm, the following is in few words the theory of their formation. When the wind gyrates rapidly round an axis, more or less inclined to the earth, the space at and about the axis is rarefied. When air charged with vapour is drawn into this rarefied space, it may be condensed into cloud or rain, but at a greater elevation into snow. Now, supposing the rain formed in the lower region to be drawn up by the ascending current into the snowy region, and so held for a short space, the drops will be frozen, and then if propelled beyond the gyrations it will fall to the ground as a shower of ordinary hail. But if in the descent they are again drawn in by the inflowing current, they will be again carried up i. to the cold region, and so acquire another coating of snow, or, if wetted in the previous descent, the water will freeze into a coat of transparent ice. In this way the globule may make a number of ascents and descents, and acquire a fresh coating each time.

From the date of Franklin's experiments even to our own day, the formation of hail has been attributed to electricity. Even so go dd an observer as P'eltier ("Météorologie," p. I I6), while rejecting Volta's theory, offers an electrical theory of his own, with the complacent remark that "Volta a placé des suppositions où je place des faits;" but De la Rive, in noticing Olmsted's theory, very properly remarks that although electricity always accompanies the formation and fall of hail, these two phenomena are not connected as cause and effect.
Highgate, N., June 20.
C. Tombinson.

\section{Curious Effects of Lightning on a Tree.}

DURING the recent thunderstorms a large elm-tree was struck by lightning in a private park at Dulwich, but the only visible effects were linear interrupted grooves about $\frac{3}{4}$ inch deep, extending down one side of the tree to the ground, where two or three depressions some 3 inches deep were found. The bark is scooped out as clearly as if done with a gouge, and the intervals are from $\mathrm{I}$ to 2 feet in length, while the grooves themselves are from $\mathrm{x}$ to 3 feet in length. The grooves are now filled with mildew, which, I take it, indicates the death of the adjacent bark. I have often seen trees which have been struck by lightning, but none in which the effects have at all resembled those I have described.

Gower Street, W.C. AlFRED S. GUBB.

\section{The Formation of Cumuli.}

A VERY perfect illustration of the method of formation of cumuli was noted by the writer recently. A perpendicular c, lumn of smoke was seen capped at a vast height hy a rounded mass of cumulus cloud having a flattened under surface. The ascending warm current being traceable by the smoke, and the cloud.cap very distinct and persistent, the appearance was very striking, the sky in the vicinity being intensely blue and otherwise cloudless.

Lyons, N.Y., June 10.

\section{A. VEEDER,}

\section{Coral Reefs.}

THE business of the surveyor abroad is not with theories. It is to collect facts ; to apply the resources under his command to the delineation of the earth's surface ; and to examine the bottom of the ocean. When he begins to thecrize, he may be suspected with some reason of bias, and of insensibly colouring his reports with preconceived notions of what he expected to find, instead of carefully storing up evidence. $\mathrm{He}$ is, however, at liberty to study the writings of our great naturalists, and to him Darwin is, at present, the great authority: not so much the young naturalist of the Beagle, as the matured thinker who, after forty years of deep research into various problems of Nature, published that edition of "Coral Reefs" which has been before the world for the last fifteen years.

With your permission, I desire to ask two or three questions of those gentlemen who are unable to reconcile their views with Mr. Darwin's theory of subsidence.

The Fiji Islands present the most complete collection of coral reefs in the world. We have there the fringe reef, the barrier, and the atoll ; islands which have a barrier all around them, others where it is sunken on one side; the island, such as Lakemba, where there is a fringe on one side and a barrier on the other; as 'Thithia, which is surrounded by fringe only. There are extinct craters, such as Fulanga, and islands with exterior rim and depression in the centre, the formation of which is apparently not due to the volcanic action; islets on the edge of atolls like Ngele Levu which are wholly coral, others of coral in the centre of lagoons. In the same locality may be found islands which have a fringe to windward and barrier to leeward, and those which have a fringe to leeward and a barrier to wind. 